\title{
Attitudes toward Chemistry, Self-Efficacy, and Learning Experiences of Pre-Service Chemistry Teachers: Grade Level and Gender Differences
}

\section{Dwi Wahyudiati}

Graduate School, Yogyakarta State University, Yogyakarta, Universitas Islam Negeri Mataram, Mataram, Indonesia, dwiwahyudiati.2017@student.uny.ac.id

\section{Eli Rohaeti}

Assoc. Prof., Yogyakarta State University, Indonesia, eli_rohaeti@uny.ac.id

\section{Irwanto}

Dr., Yogyakarta State University, Yogyakarta, Indonesia,dr_irwanto@yahoo.com

\section{Antuni Wiyarsi}

Assoc. Prof., Yogyakarta State University, Yogyakarta, Indonesia, antuni_w@uny.ac.id

\section{Lalu Sumardi}

Mataram University, West Nusa Tenggara, Indonesia, lalu.unram@gmail.com

This study aims to explore grade level and gender differences in the attitudes toward chemistry (ATC), self-efficacy (SE), and learning experiences (LE) of preservice chemistry teachers. A total of 191 pre-service chemistry teachers were taken as the sample through cluster random sampling technique. This crosssectional survey collected the data using CAEQ questionnaire and interview. MANOVA test was carried out to analyze the quantitative data on the significance level .05 , while the qualitative data were analyzed using Patton qualitative data analysis procedure. The findings showed that: 1) the LE level of the preservice chemistry teachers was the highest compared to SE and ATC ; 2) there was a difference of ATC and SE between the freshman and sophomore groups, and there was a difference in terms of ATC between freshman and junior categories, yet no different in terms of LE based on this category; and that 3) there was no difference of ATC, SE, and LE based on gender. The results accord with the interview findings in which both male and female student teachers have positive attitudes toward learning chemistry, and there was a difference of ATC, SE, and LE between freshman, sophomore, and junior.

Keywords: attitude toward chemistry, self-efficacy, learning experiences, pre-service chemistry teachers, learning

Citation: Wahyudiati, D., Rohaeti, E., Irwanto, Wiyarsi, A., \& Sumardi, L. (2020). Attitudes toward Chemistry, Self-Efficacy, and Learning Experiences of Pre-Service Chemistry Teachers: Grade Level and Gender Differences. International Journal of Instruction, 13(1), 235-254. https://doi.org/10.29333/iji.2020.13116a 


\section{INTRODUCTION}

Lecturers are expected to be able to promote pre-service chemistry teachers' competency. The quality of chemistry teacher candidates in the globalization era should not only center on the academic prestige's but also focus on the development of their soft skills, one of which is the affective domain. It, as learning outcomes, includes attitudes, motivation and self-confidence (Cheung, 2011). For this reason, it is of paramount importance to escalate the attitude as the learning objective (Popham, 2005; Cheung, 2007; Calik, Ultay, Kolomuc, \& Aytard, 2015), which, however, remains ignored in the sphere. As a consequence, it adversely impacts on the students' lack of chemistry attitudes on the primary, secondary and tertiary levels (Villafane, \& Lewis, 2016; Stark, \& Gray, 1999; Taber, 2011; Irwanto, Rohaeti, \& Prodjosantoso, 2018a; Ismiani, Syukri, \& Wahyudiati, 2017).

Chemistry attitude refers to the individual tendency to figure out a certain problem in a systematic way through the use of scientific method (Prabowo, 2015). Dalgety, Coll, and Jones (2003) states that there are several indicators of this attitude, which include attitudes toward chemistry (ATC), self-efficacy (SE), and learning experiences (LE).The three indicators are interrelated, which means that the higher attitudes toward chemistry, the higher the self-efficacy and learning experience the students will have and vice versa. Villafane, Garcia, and Lewis (2014) define chemistry self-eficacy as the belief the students have about their ability to perform their chemistry tasks. However, the research examining ATC, LE and SE of pre-service chemistry teachers' remains scanty, most of which focus on attitudes toward science (Calik, Ozsevgez, Ebenezer, Artun, \& Kucuk, 2014; Gardner, 1975; Osborne, Simon \& Collins, 2003). Furthermore, the measurement of ATC, LE and SE skills of pre-service chemistry teachers remains scantily documented (Ferrel \& Barbera, 2015; Villafane, Garcia, \& Lewis, 2014; Mataka, \& Kowalske, 2015), not to mention the absence of the study examining the three domains at the same time. For this reason, research on examining pre-service chemistry teachers' ATC, LE and SE is of paramount importance to carry out. Drawing on the gap of the research, the novelty of the current study lies in the measurement of the three aforementioned domains (ATC, LE, and SE) concurrently based on gender and grade levels. Hence, the current study will contribute the current existing literature in the sphere of chemistry education, which encapsulates the presence of positive correlation between the three variables measured and students' academic prestige (Calik, Ozsevgez, Ebenezer, Artun, \& Kucuk, 2014; Dalgety, Coll, \& Jones, 2003; Zusho, Pintrich, \& Coppola, 2003). For this reason, ATC, SE, and LE are key factors to be taken into account in chemistry education research either in the primary secondary or tertiary levels.

ATC, LE and SE of the pre-service chemistry teachers should be developed to attain the chemistry learning goals, which comprise cognitive, affective, and psychomotoric domains. Such a learning objective can be supported by learner-centered pedagogy through the application of innovative learning strategy along with the improved quality of instructors (Calik, Ozsevgez, Ebenezer, Artun, \& Kucuk, 2014; Villafane, Garcia, \& Lewis, 2014). The learning process that sparks students' active participation in 
constructing the conceptual knowledge and professional experience in laboratory will promote their self-efficacy and positive attitude development toward chemistry learning, which may positively impact on their ATC, LE and SE. Nonetheless, the empirical evidence showed that teaching programs at the Indonesian higher education level remain adopting the teacher-centered learning approach and focus on the development of conceptual knowledge rather than the escalation of the attitude and skills that contribute to the low level of the students' ATC, LE, and SE (Mukhtar, 2017; Wahyudiati, 2010; Nurhayati, 2009; Nurlita, 2008; Irwanto, Saputro, Rohaeti \& Prodjosantoso, 2018, 2019; Irwanto et al., 2018b; Ibrahim, 2010; Wahyudiati, 2016, Wiwit, Ginting, \& Firdaus, 2013). Drawing on the empirical evidence, it is unveiled that the problem of the chemistry learning has been the pervasive use of monotonous and less experimental teaching methods. Previous studies also show that the pedagogical environment, employment of innovative technologies, and learning strategies have been strongly associated with the improvement of students' ATC, LE, and SE (Osborne, Simon, \& Collins, 2003; Calik, Ozsevgez, Ebenezer, Artun, \& Kucuk, 2014; Myers \& Fouts, 1992; Villafane, Garcia, \& Lewis, 2014). For this reason, various innovative strategies for learning and the professional improvement of student teachers' instructors are needed to improve the quality of chemistry learning (Osborne, Simon, \& Collins, 2003; Calik, Ozsevgez, Ebenezer, Artun, \& Kucuk, 2014).

In addition to the aforementioned factors, other relevant literature also unveils that ATC, LE and SE are strongly correlated with students' gender and education levels. Studies by Cheung (2007) and Calik, UItay, Kolomuc, and Aytard (2015) uncovered that students' ATC, LE and SE were different based on their gender and grades. This has been evidenced by other studies carried out in several countries, to name a few, Villafane, Garcia, and Lewis, (2014), Xu, Villafane, and Lewis (2013) in USA; Calik, Ozsevgez, Ebenezer, Artun, and Kucuk (2014) in Turky; Cheung (2011) in Hongkong; Harvey and Stables (1986) in England; Salta and Tzougraki (2004) in Greek; and Zeidan and Jayosi (2015) in Palestine, all of which demonstrated that gender and education levels were strongly correlated with students' ATC, LE and SE. The aforementioned studies document students' current state of ATC, LE and SE. However, the study documenting students' ATC, LE and SE in the Indonesian Higher Education context remains under researched. For this reason, it is of paramount importance to examine the factual condition of the chemistry student teachers' ATC, LE and SE based on their gender and education levels.

With reference to the urgency of the current study, it is expected that the findings of this study will provide evidence on the current state of pre-service Chemistry teachers' ATC, LE and SE, which remains scantily documented in the Indonesian higher education context. Furthermore, the significance of the current study include 1) documenting the factual condition of the Chemistry student teachers' ATC, LE and SE in Higher Education context; 2) being the foundation for planning and implementation of chemistry learning that enable the development of the Chemistry student teachers' SE; 3) being a refence for promoting the Chemistry student teachers' ATC and LE in learning; 4) improving the pre-service Chemistry teachers' quality through promoting their ATC, LE and SE. The current study aims to describe the current condition of and 
discover the difference of the pre-service Chemistry teachers' ATC, SE and LE based on their gender and education levels.

\section{METHOD}

\section{Research Design}

This study employed a cross-sectional survey design (Creswell, 2009; Iyankova, Creswell, \& Stick, 2006) collecting both the quantitative and qualitative data. Interviews, carried out through focus group discussion (with an indebt-interview technique), were performed to collect the qualitative data that provides the explanation for the quantitative findings garnered from the questionnaire (Ismail, \& Jarrah; 2019). The strength of this research design lies on its affordance to measure the correlation between two or more variables and provides the interpretation of the situation of the objects under study (Stangor, 2004; Cohen, Manion \& Morrison, 2007).

\section{Samples}

The samples of this study were taken from three different universities, namely Universitas Islam Negeri Mataram, Universitas Mataram, and IKIP Mataram. The total number of the participants was 191 pre-service Chemistry teachers comprising of junior (26.94\%), sophomore (30.05\%), and freshman (43.00\%), and 31.94\% male, as well as $68.06 \%$ female (see Table 1). During the survey, 130 female and 61 male participants were selected as the samples determined through cluster random sampling technique (Fowler, 2002). The focus group interview with an in-depth interview technique (Creswell, 2009) was applied involving 5 lecturers and 30 student teachers.

Table 1

The Characteristics of Demographic samples

\begin{tabular}{llll}
\hline Grade Level & Female & Male & Total \\
\hline Freshman $\left(1^{\text {st }}\right.$ grade $)$ & 58 & 25 & 83 \\
Sophomore $\left(2^{\text {nd }}\right.$ grade $)$ & 38 & 20 & 58 \\
Junior $\left(3^{\text {th }}\right.$ grade $)$ & 34 & 16 & 50 \\
Total & 130 & 61 & 191 \\
\hline
\end{tabular}

\section{Data Collection}

The data were collected in order using survey and interview (Teddlie \& Tashakkori, 2009). The first phase was to distribute the questionnaires of CAEQ to three different universities: IKIP Mataram, Universitas Mataram, and Universitas Islam Negeri Mataram, which was followed by interviews based on the result of CAEQ analysis by means of in-depth interview technique. The selection of the participants from the three universities were based on purposive random sampling technique (Creswell, 2009) with a signed agreement from the Chemistry study program at the three universities, based on the students' willingness to participate in the questionnaire, willingness of the lecturers and students for the interview, and the availability of laboratory for practicum. The four criteria above are the primary reasons for the researcher to select the respondents. The questionnaires were handed out to the three different grades, namely freshman, sophomore, and junior at the three aforementioned universities simultaneously for three 
weeks. To ensure the full participation of the respondents in the survey, assistant researchers were involved in distributing and collecting the questionnaires. Before distributing the questionnaires, the respondents were told about the objective and convinced that their participation was voluntary and may not participate. The Focus group interview involved five lecturers and 10 student teachers from each of the three categorical variables, which means that there were 5 lecturers and 30 pre-service chemistry teachers participating in the focus group interview.

\section{Questionnaire}

The questionnaires employed in this study were adopted from CAEQ questionnaires (chemistry attitudes and experiences questionnaire) developed by Coll, Dalgety, and Salter (2002). This CAEQ questionnaire includes three constructs, namely Attitude toward chemistry (ATC), Learning experiences (LE), and Self-efficacy (SE) that entails positive and negative five-Likert scale questions and statements. The ATC questionnaire consisted of 21 items pertinent to the students' attitude toward chemists, skills of chemists, attitude toward the role of chemistry in society, leisure interest in chemistry, and career interest in chemistry. The LE questionnaire comprised 31 items related to lecture learning experiences, tutorial and tutor learning experiences, practical learning experiences, and demonstrator learning experiences. The SE questionnaire entailed 17 items that measure the self-efficacy level of the students in solving chemistry problems, experimental performance, proving theories through experiments, interpreting the experimental results, and concluding as well as making a report of the results. Construct and face-validity were applied before the distribution of the CAEQ questionnaire. The instruments went through constructive and face validity by six experts from three different universities. After being validated, an empirical test was carried out to measure the reliability of the instruments. The statistical computation yielded that Cronbach Alpha coefficient value was $\alpha=.90$. This evidenced that the instrument was reliable to use (Hair, Black, Babin, \& Anderson, 2006).

\section{Focus group interview}

Nine questions for the focus group interview were developed by the researcher to garner the qualitative data that corroborate the quantitative data gained through the questionnaire. Each variable was represented by three questions (ATC, LE, and SE), which accumulates nine questions. Before applied, the questions were validated by experts from three different universities who are the experts in linguistics and content analysis. Purposive random sampling technique was applied for the selection of the interviewees (Creswell, 2009) that involved five lecturers and thirty students. The number was determined based on the willingness of the anonymous participants to partake in the interview. The involvement of both the lecturers and students in the interview was aimed at corroborating the statistical results from the questionnaire. For the ethical purposes, the identity of the respondents remained anonymous and they were allowed to freely express their rejection and agreement in participating in the qualitative data collection. In-depth interview technique was deployed for the data collection in that it allowed the participants to freely express their opinions and present their fundamental reasons (Creswell, 2009). 


\section{Data Analysis}

Two data analyses procedures were applied to analyze both the quantitative and qualitative data. First, the quantitative data as collected through the CAEQ questionnaire were analyzed using Manova formula because it aims to measure the correlation between two or more variables (Hair, Black, Babin, \& Anderson, 2010). The prerequisite of Manova was supported by the result of Levene's test ATC, SE, and LE with $p>0.05$ (homogenous) that it complied with the Manova assumption (Bernard, 2000). The normality test also yielded $p>0.05$ value, which means that the data were normally distributed. For the multicollinearity test, it was found the value of VIF $=0.40$ (no multicollinearity). Further, the matrix scatter plot indicated that there was a positive correlation between each pair of the variables. Based on the prerequisite test results, the Manova test was carried out. The other data analysis for the qualitative findings was categorization or repeated pattern drawing on the qualitative data analysis by Patton (2002) by thoroughly and specifically looking at the data from the focus group interview. The primary reason for the employment of the data analysis procedure was to gain the themes or repeated patterns of the data, which accorded with the purposes of the research and corroborated the quantitative data garnered from the questionnaire. In addition, the use of Patton method could be helpful for identifying the presence of unanticipated elements during the interview (Ismail \& Jarrah, 2019).

The data were arranged and categorized into themes whose items were frequently calculated, which were consequently noted to identify the repeated patterns. The qualitative data were used to explain the quantitative findings. The current study put more emphasis on the quantitative data that aimed to investigate the consistence and difference among the filled questionnaires. For this reason, the qualitative evidence corroborated that of quantitative.

\section{FINDINGS}

The level of preservice Chemistry teachers' ATC, SE, and LE based-on gender and education levels were presented in terms of average and standard deviation as seen in the table 2. The statistical evidence showed that the LE level of the pre-service teachers was the highest followed by SE and ATC. The highest mean scores of learning experiences were found on the female and freshman categories, 96.55 (see Table 2). For the ATC level, the male pre-service chemistry teachers were found to have higher level than that of their female counterparts for the sophomore group, which was also the same to the SE level in which the male student teachers gained higher level than female for the sophomore group. Lowest SE level was found to be on the female student teachers for the Sophomore group, 69.195. To further explore the finding, the quantitative data were completed with the qualitative findings through interviews (described in the discussion). 
Table 2

Mean Scores ATC, SE and LE based-on Gender and Grades Levels

\begin{tabular}{|c|c|c|c|c|}
\hline & Gender & Grades & Mean & $\mathrm{SD}$ \\
\hline \multirow{6}{*}{ Attitude Chemistry } & Male & Freshman & 79.045 & 5.63 \\
\hline & & Sophomore & 77.452 & 8.61 \\
\hline & & Junior & 76.290 & 8.43 \\
\hline & Female & Freshman & 79.677 & 5.60 \\
\hline & & Sophomore & 73.277 & 4.98 \\
\hline & & Junior & 75.559 & 6.24 \\
\hline \multirow{6}{*}{ Self-Efficacy } & Male & Freshman & 81.176 & 17.56 \\
\hline & & Sophomore & 74.706 & 18.21 \\
\hline & & Junior & 78.309 & 20.00 \\
\hline & Female & Freshman & 81.643 & 19.77 \\
\hline & & Sophomore & 69.195 & 19.65 \\
\hline & & Junior & 79.585 & 17.81 \\
\hline \multirow{6}{*}{ Learning Experiences } & Male & Freshman & 95.273 & 4.82 \\
\hline & & Sophomore & 94.545 & 6.85 \\
\hline & & Junior & 95.739 & 3.88 \\
\hline & Female & Freshman & 96.552 & 7.09 \\
\hline & & Sophomore & 94.498 & 5.80 \\
\hline & & Junior & 94.251 & 3.76 \\
\hline \multirow{6}{*}{ Overall } & Male & Freshman & 85.165 & 6.92 \\
\hline & & Sophomore & 82.234 & 8.09 \\
\hline & & Junior & 83.446 & 6.33 \\
\hline & Female & Freshman & 85.957 & 7.85 \\
\hline & & Sophomore & 78.989 & 8.02 \\
\hline & & Junior & 83.632 & 6.66 \\
\hline
\end{tabular}

The Manova statistical evidence indicated that there was a difference of the ATC, SE, and LE levels among the three education levels given the $p$ value $<0.05$ (see Table 3 ), which means that the null hypothesis was rejected. Unlike the education levels categories, it was found that there was no difference in terms of ATC, SE, and LE between the male and female categories given the $p$ value $>0.05$, meaning that the null hypothesis $\left(\mathrm{H}_{0}\right)$ was accepted.

Table 3

The Result of Manova Test of the ATC, LE and SE Levels based on Gender and Grades Levels

\begin{tabular}{lllll}
\hline Effect & & Value & $F$ & $p$ \\
\hline Gender & Pillai's Trace & .009 & .590 & .622 \\
& Wilks' Lambda & .991 & .590 & .622 \\
& Hotelling's Trace & .010 & .590 & .622 \\
& Roy's Largest Root & .010 & .590 & .622 \\
\hline Grades & Pillai's Trace & .147 & 4.935 & .000 \\
& Wilks' Lambda & .854 & 5.046 & .000 \\
& Hotelling's Trace & .168 & 5.156 & .000 \\
& Roy's Largest Root & .154 & 9.28 & .000 \\
\hline
\end{tabular}

The significant test result of Manova was also supported by the Levene's test with the total value of $p>0.05$ (see Table 4), meaning that there was no difference among the 
variance (the null hypotheses was accepted or the variants were the same), so that this met the Manova assumption.

Table 4

Levene's Test Result (Homogeneity Test)

\begin{tabular}{lllll}
\hline & $F$ & $d f 1$ & $d f 2$ & $p$ \\
\hline Attitude Chemistry & 1.396 & 5 & 185 & .228 \\
Self-Efficacy & .140 & 5 & 185 & .983 \\
Learning Experiences & .846 & 5 & 185 & .519 \\
\hline Overall & .380 & 5 & 185 & .862 \\
\hline
\end{tabular}

The next data analysis was test Between-Subjects Effects to examine the difference of each factor toward the dependent variables. The result indicated that there was no difference of the ATC, SE, and LE based on the gender category given the $p$ value > .05 (see Table 5). On the other hand, for the education levels, it was found that there was difference in terms of the two variables $\operatorname{ATC}(p=.000)$ and $\operatorname{SE}(p=.005)$, yet there was no difference in terms of the student teachers' LE given $p=.118$.

Table 5

Test result of Between-Subjects Effects ATC, LE and SE

\begin{tabular}{llll}
\hline Effect & Variable Dependent & F & Sig. \\
\hline Gender & Attitude Chemistry & .590 & .204 \\
& Self-Efficacy & .590 & .681 \\
& Learning Experiences & .590 & .882 \\
& Overall & .590 & .506 \\
\hline Grades & Attitude Chemistry & 4.935 & .000 \\
& Self-Efficacy & 5.046 & .005 \\
& Learning Experiences & 5.156 & .188 \\
& Overall & 9.28 & .000 \\
\hline
\end{tabular}

Another statistical analysis examines the difference of ATC, SE, and LE between the two variables, gender and education levels, using Multiple Comparisons Tukey HSD test, showed that there was a difference of the student teachers' ATC between the freshman, sophomore, and junior (see Table 6). Similarly, there was a difference in terms of SE between the freshman and sophomore given $p=.004$. Nonetheless, there was no difference for the LE between the three education levels categories $(p>.05)$. 
Table 6

Test Result of Multiple Comparisons ATC, SE and LE based-on Education Levels

\begin{tabular}{|c|c|c|c|c|c|}
\hline Dependent Variable & & Grades & Grades & Mean & Sig. \\
\hline \multirow{6}{*}{$\begin{array}{l}\text { Attitude Chemistry } \\
\text { (ATC) }\end{array}$} & \multirow[t]{6}{*}{ Tukey HSD } & \multirow[t]{2}{*}{ Freshman } & Sophomore & 4.7706 & .000 \\
\hline & & & Junior & 3.6934 & .004 \\
\hline & & \multirow[t]{2}{*}{ Sophomore } & Freshman & -4.7706 & .000 \\
\hline & & & Junior & -1.0772 & .649 \\
\hline & & \multirow{2}{*}{ Junior } & Freshman & -3.6934 & .004 \\
\hline & & & Sophomore & 1.0772 & .649 \\
\hline \multirow{6}{*}{$\begin{array}{l}\text { Self-Efficacy } \\
\text { (SE) }\end{array}$} & \multirow[t]{6}{*}{ Tukey HSD } & \multirow[t]{2}{*}{ Freshman } & Sophomore & 10.4071 & .004 \\
\hline & & & Junior & 2.3260 & .772 \\
\hline & & \multirow{2}{*}{ Sophomore } & Freshman & -10.4071 & .004 \\
\hline & & & Junior & -8.0811 & .072 \\
\hline & & \multirow[t]{2}{*}{ Junior } & Freshman & -2.3260 & .772 \\
\hline & & & Sophomore & 8.0811 & .072 \\
\hline \multirow{6}{*}{$\begin{array}{l}\text { Learning Experiences } \\
\text { (LE) }\end{array}$} & \multirow[t]{6}{*}{ Tukey HSD } & \multirow[t]{2}{*}{ Freshman } & Sophomore & 1.6524 & .222 \\
\hline & & & Junior & 1.4392 & .351 \\
\hline & & \multirow[t]{2}{*}{ Sophomore } & Freshman & -1.6524 & .222 \\
\hline & & & Junior & -.2132 & .980 \\
\hline & & \multirow{2}{*}{ Junior } & Freshman & -1.4392 & .351 \\
\hline & & & Sophomore & .2132 & .980 \\
\hline \multirow{6}{*}{ Overall } & \multirow{6}{*}{ Tukey HSD } & \multirow{2}{*}{ Freshman } & Sophomore & 5.6101 & .000 \\
\hline & & & Junior & 2.4862 & .155 \\
\hline & & \multirow[t]{2}{*}{ Sophomore } & Freshman & -5.6101 & .000 \\
\hline & & & Junior & -3.1238 & .080 \\
\hline & & \multirow[t]{2}{*}{ Junior } & Freshman & -2.4862 & .155 \\
\hline & & & Sophomore & 3.1238 & .080 \\
\hline
\end{tabular}

The test result of homogenous subsets on ATC based on education levels showed that, in subset 1 containing the mean score of sophomores and junior, the significant value was 1.00 (see Table 7). This means that there was no statistical difference between the two categories, sophomore and junior, yet there was a difference from that of freshmen group given its subset position $2(p=1.000)$.

Table 7

Test of Homogeneous Subset ATC based on Education Levels

\begin{tabular}{lllll}
\hline & Grades & N & Subset & \\
\hline & & & 1 & 2 \\
\hline Tukey HSD ${ }^{\mathrm{a}, \mathrm{b}}$ & Sophomore & 58 & 74.716 & \\
& Junior & 50 & 75.793 & 79.487 \\
& Freshman & 83 & & 1.000 \\
\hline
\end{tabular}

Test of homogenous subsets on SE based on genders showed that, in the subset 1 comprising sophomore and junior categories (subset 1), was statistical difference (see Table 8). Likewise, there was no difference between the junior and freshmen categories given their position in subset $2(p=.777)$. 
Table 8

Test of Homogeneous Subset SE based on Education Levels

\begin{tabular}{lllll}
\hline & Grades & $\mathrm{N}$ & Subset & \\
\hline & & & 1 & 2 \\
\hline Tukey HSD ${ }^{\mathrm{a}, \mathrm{b}}$ & Sophomore & 58 & 71.095 & \\
& Junior & 50 & 79.176 & 79.176 \\
& Freshman & 83 & & 81.502 \\
& Sig. & & .051 & .777 \\
\hline
\end{tabular}

A different statistical evidence resulted from the test of homogenous subsets on LE was no difference between the three education levels, sophomore, junior, and freshman (being in one subset) given the value $p=.261$ (Table 9).

Table 9

Test of Uji Homogeneous Subset on LE based-on Education Levels

\begin{tabular}{llll}
\hline & Grades & N & Subset \\
\hline Tukey HSD & & & 1 \\
& Sophomore & 58 & 94.514 \\
& Junior & 50 & 94.727 \\
& Freshman & 83 & 96.166 \\
Sig. & & .261 \\
\hline
\end{tabular}

Generally, the statistical evidence resulted from the test of homogenous subsets ATC, SE and LE based on the education levels indicated that there was no statistical difference between the three categorical variables (Table 10). Similar result was also found between the junior and freshman given the $p$ value $=.162$.

Table 10

Test of Homogeneous Overall (ATC, SE and LE) based on Education Levels

\begin{tabular}{lllll}
\hline & Grades & $\mathrm{N}$ & Subset & \\
\hline & & & 1 & 2 \\
\hline Tukey HSD & & & \\
& Sophomore & 58 & 80.109 & \\
& Junior & 50 & 83.232 & 83.232 \\
& Freshman & 83 & & 85.719 \\
& Sig. & & .058 & .162 \\
\hline
\end{tabular}

\section{DISCUSSION}

The interesting finding of the current study was that the LE level of the preservice chemistry teachers was the highest compared to SE and ATC. For the ATC level the male preservice chemistry teachers were found to have higher level than that of their female counterparts for the sophomore group. Likewise, the SE level in which the male student teachers gained higher level than female for the sophomore group. This is because the male has a higher perception, experience, motivation, and interest in carrying out chemical research activities that will later support a career in the future. The results of this study are relevant to previous research which shows that men are more interested in chemical topics and have more positive attitudes towards chemistry, and show high ability in chemical research (Adesoji \& Raimi, 2004; Jones, Howe, \& Rua, 2000; Harvey \& Stables, 1986). In addition, male students prefer chemical laboratory work compared to female (Kassim, 2014; Wolf \& Fraser, 2008; Jones \& 
Wheatley, 1990). Furthermore, Catsambis (1995) found that male likely to enjoy science learning and thought that science would be useful for their future, and not afraid to ask questions in class than their female counterparts. The empirical finding was supported by the following qualitative evidence collected from the interview:

WD (lecturer) "male students tend to have stronger belief and motivation in learning and doing laboratory tasks in that they tend to be more scholarly prestigious than their female counterparts".

$\mathrm{Al}$ (male) "I am very interested in conducting experiments in the laboratory because it is very supportive of my career in the future".

Ad (male) "The experience of doing experimental activities has made me very motivated in learning chemistry because it provides experiences that can be utilized in everyday life".

An (Female) "I am more motivated in completing lecture assignments than doing research in the laboratory".

The other interesting finding of this current study was that the highest mean scores of learning experiences were found on the female and freshman categories. Likewise, for the ATC, SE and LE level the female preservice chemistry teachers were found to have higher level than that of their male counterparts for the freshman group. This finding accorded with that of study by Calik, Ozsevgez, Ebenezer, Artun, and Kucuk, (2014), Villafane and Lewis (2016), and Smist (1993), which discovered that female students possessed higher levels of ATC. Similarly, Villafane, Garcia, and Lewis (2014), and Zeldin, Britner, and Pajares (2008) indicated that gender had an influence on the students' SE level. It was further argued that SE had significant influence on individual characteristics with their interests (Schiefele, 1991; Renninger, \& Hidi, 2002). Apart from the self-efficacy, the students' LE significantly influenced students' positive attitudes toward learning chemistry, particularly regarding the implementation of learning based inquiry (Ayyildiz \& Tarhan, 2012; Hugerat \& Kortam, 2014). The tendency of women to have higher levels of ATC, SE and LE than their male counterparts was because of their having more positive interests, self-confidence, gritty to do homework, and chemistry attitudes (Weiner, 1985; Calik, Ozsevgez, Ebenezer, Artun, \& Kucuk, 2014; Villafane, Garcia, \& Lewis, 2014; Zeldin, Britner, \& Pajares, 2008; Britner, \& Pajares, 2001). The empirical finding was supported by the following qualitative evidence collected from the interview:

To $\mathrm{Yu}$ (lecturer) "female students tend to have stronger belief and motivation in learning and doing their tasks in that they tend to be more scholarly prestigious than their male counterparts".

$\mathrm{Ra}$ (female) said, "I am captivated to learn chemistry because it related to my everyday life, so I do my best to gain a maxim result for this course". 
$\mathrm{Ni}$ (female) opined, "I do believe in my learning experiences that I will be able to improve my academic attainment, particularly the ones I learn from my practicum and lectures given by the lecturer".

$\mathrm{Mz}$ (male) said, "I think my ability was lower than my other friends', which discouraged me to do my assignments".

Other empirical evidence also unveiled the level of pre-service chemistry teachers' ATC, SE, and LE based on their education levels. It was found that freshmen tend to have the highest level of ATC, SE, and LE compared to their counterparts in sophomore and junior levels. This indicates that the increase in ATC, self-efficacy and learning experiences does not correspond to the length of studies. Such a condition is caused by the fact that the scientific practicum of science classes has been monotonous in each semester, in which it was more teacher-centered, less innovative and more emphasis on cognitive aspects (Zeidan \& Jayosi, 2015; Cheung, 2007, Hofstein, Ben-Zvi, Samuel, \& Tamir, 1977; Ismiani, Syukri, \& Wahyudiati, 2017; Villafane \& Lewis, 2016). The findings were justified by various studies discovering that the ATC, SE and LE do not develop in the later semester (Calik, Ultay, Kolomuc, \& Aytard, 2015), not to mention the presence of declined positive attitudes of the students in schools (Simpson, \& Oliver, 1985; Hill, Atwater, \& Wiggins, 1995). Other survey research also discovered that female in freshman grade have the highest level of ATC, SE, and LE, which was supported by the empirical evidence in the interview beneath:

$\mathrm{Na}$ (Junior) said, "the learning experiences I gained in the previous semesters do not differ significantly from what I get in the current term because the learning strategies used are the same, lecture-based learning".

Fr (Freshman) opined, "I become more captivated to learn chemistry inasmuch as I got learning experiences not only from the normal classes but also from the practicum for all skills courses in the first year".

Ha (Sophomore) stated, "The lecture system and practicum activities between the first and second semester do not significantly differ because the tasks remain like practicing food recipe, which make me passive and dependent on the practicum handbook".

However, an interesting empirical finding was that the freshmen group had higher ATC, $\mathrm{SE}$, and LE compared to sophomore and junior groups. On one side, there was a consistency between the quantitative and qualitative findings as enumerated before. On the other side, contradictory findings were also found. This was evidenced by the qualitative evidence from the interview with the lecturers, which highlighted that their level of education was equivalent to level of ATC, SE, and LE. The finding was supported by Ra (junior) who stated "the learning experience in the class and practicum activities that I had in the first and second years was very useful and helpful for me to understand more complex chemistry concept and for me to operate practicum with appropriate procedures". Likewise, Sr (sophomore) said "in the first year, my selfconfidence in carrying out practicum tended to be low because of lack of experience, yet with the first-year experience, I could be more confident and had positive effects toward my academic prestige". This finding concurs with previous research findings that 
unveiled grade level positively contributed to the level of ATC, SE, and LE development along with the development of learning experience in each semester (Dalgety \& Coll, 2006; House, 1995; Menis, 1989; Doherty \& Dawe, 1985; Villafane, Garcia, \& Lewis, 2014). However, contradictory findings evidence that ATC, SE, and LE did not undergo any development in the following semester (Calik, UItay, Kolomuc, \& Aytard, 2015). The inconsistency of the research findings was due to the contextual learning differences, including the different use of methods or learning strategies applied for the teaching of chemistry. Numerous research findings of previous studies also proved that learning environment, the use of innovative technology, method and learning strategy were found to significantly contribute to the increased level of students' ATC, LE and SE (Calik, Ozsevgez, Ebenezer, Artun, \& Kucuk, 2014; Osborne, Simon, \& Collins, 2003; Villafane, Garcia, \& Lewis, 2014).

Another finding also showed that there was a difference of ATC, SE, and LE based on the education levels, yet it did not happen to gender category. This finding is justified by empirical evidence of studies by Concannon, and Barrow (2012), Calik, Ozsevgez, Ebenezer, Artun, and Kucuk (2014), Bui and Alfaro (2011), and Dhindsa \& Chung (2003), which unveiled that ATC, SE, and LE did not correspond to the difference in gender. In addition, self-efficacy of the student teachers was different in terms of grade levels that influence their chemistry attitudes and learning experiences (House, 1995; Menis, 1989; Doherty \& Dawe, 1985). The presence of difference on ATC and SE based on the education levels was caused by the improvement of learning experiences gained from each term (Dalgety \& Coll, 2006). A myriad of earlier studies also showed that the learning environment, innovative use of technologies, and learning strategies have an impact on the student teachers' chemistry attitudes and learning experiences (Osborne, Simon, \& Collins, 2003; Calik, Ozsevgez, Ebenezer, Artun, \& Kucuk, 2014; Myers \& Fouts, 1992). Furthermore, SE was found to influence the academic performance that impacts on the students' endeavor, grit, and emotional reaction toward their given tasks (Lopez, \& Lent, 1992; Villafane, Garcia, \& Lewis, 2014; Pajares, \& Kranzler, 1995). The findings from questionnaire accords with the ones collected from the interview. For Ar (Sophomore) "the assignment forms the first semester gives positive impacts on my learning experience, self-confidence, and belief making it stronger than the last semester". Likewise, Ha (Junior) stated "the learning experiences I got from the first and second semesters are pretty helpful for the accomplishment of my practicum and enable me to easily work on my task in the following semester". Similarly, Vh (Freshman) said "the learning experience in the first year encourages me to learn chemistry and made me believe that I can finish my chemistry tasks in the following semester". Drawing on the empirical evidence above, the chemistry learning should be well-designed in that it develops the student teachers' mastery of concept and self-efficacy (Schmid, Youl, George, \& Read, 2012; Youl, Read, George, Masters, Schimd, \& King, 2012).

To strengthen the previous findings, the measurement of ATC, SE and LE levels was carried out more specifically. It was found that the level of ATC was different between the education levels, freshman, sophomore, and junior, yet it was not different in terms of SE level. This finding is justified by other research discovering that the grade levels 
correspond to students' ATC and SE levels (House, 1995; Menis, 1989; Villafane, Garcia, \& Lewis, 2014), yet it did not accord with gender (Concannon, \& Barrow, 2012; Calik, Ultay, Kolomuc, \& Aytard, 2015).The statistical evidence is justified by the following interview:

Ra (Junior) "I feel motivated to learn chemistry and carry out practicum tasks compared to my first and second year of studies because the learning experiences I gained from the years allow me to better understand the materials and trial procedures more precisely".

Ms (Sophomore) "In the first semester, I found it difficult to acquire materials' and apply experiments because of my lack of experience on the secondary level. However, in the second year, I feel more enjoyable to participate in the lecture, so I do not face any difficulty as I used to be".

$\mathrm{Nu}$ (Freshman) "my learning experience in the first semester made me believe in myself and encouraged my self-guided learning and capitalized on it for the following semester so that it allows me to improve my academic performance".

Self-efficacy, learning experience, chemistry attitudes of the students have positive correlation with their academic prestige's. This is justified by the previous studies which unveiled that SE, LE, and ATC have positive impacts on the students' chemistry learning outcomes at tertiary level (Ferrel \& Barbera, 2015; Calik, Ozsevgez, Ebenezer, Artun, \& Kucuk, 2014; Myers \& Fouts, 1992; Dalgety, Coll, \& Jones, 2003; Zusho, Pintrich, \& Coppola, 2003; Uzuntiryaki \& Aydin, 2009). Thus, ATC, SE, and LE are the key factors to be taken into account for carrying out chemistry research in primary, secondary, and tertiary levels. In addition to that, the presence of the difference between ATC, SE, and LE based on the grade levels indicates that the lecture should priorities the development of students' academic attainment at higher education level. Furthermore, high education institutions should facilitation lecturers to design, apply and evaluate the chemistry learning to generate innovative and collaborative learning. For this reason, the learning process of chemistry at higher education level can be elevated.

\section{CONCLUSION AND SUGGESTIONS}

Drawing on the research findings, it can be concluded that: 1) the LE level of the preservice chemistry teachers was the highest compared to SE and ATC; 2) there was a difference of ATC and SE between the freshman and sophomore groups, and there was a difference in terms of ATC between freshman and junior categories, yet no different in terms of LE based on this category; and that 3) there was no difference of ATC, SE, and LE based on gender. The results accord with the interview findings in which both male and female student teachers have positive attitudes toward learning chemistry, and there was a difference of ATC, SE, and LE between freshman, sophomore, and junior. For this reason, it is suggested that the higher education instruction and lecturers prioritize the development of ATC, SE, and LE in the learning of chemistry, so it can enhance the scholarly prestige of the pre-service chemistry teachers. In addition to that, drawing on the research findings, the best strategy and process of learning that can elevate the level of ATC, SE, and LE was through the active involvement of the students in the class (the 
application of active and innovative learning), combined with the experimental activities. Such a blend of learning will create a meaningful learning experience that facilitates the empirical generation of the conceptual understanding through experiment or other scientific inquiries, resulting in the escalation of ATC, SE, and LE level of the pre-service chemistry teachers. What is more, institutional supports are highly expected as the policy maker in the composition of curriculum that orients both toward the development of cognitive domain and attitude and psychomotoric of the student teachers.

The limitation of the current study is the inadequate number of respondents with relatively short period of field research, 3 months. It also related to the interview process which does not involve all the participants. Therefore, as a reference for the future research, the respective researchers are expected to involve more respondents with longer period of field research (1 semester). In addition, this cross-sectional mixed method research involved three universities. This needs to be extended into longitudinal study that involves more samples with more comprehensive variables. For more depth inquiry, it is necessary to investigate how ATC, SE, and LE are developed effectively at university. The findings of this study are important to facilitate future studies regarding how to improve the cognitive, affective, and pyschomotoric domains in the lecture and chemistry laboratory practicum, which remains scantily documented.

\section{REFERENCES}

Adesoji, F. A., \& Raimi, S. M. (2004). Effects of enhanced laboratory instructional technique on senior secondary student's attitude toward chemistry in Oyo township, Oyo state, Nigeria. Journal of Science Education and Technology, 13(3), 377-385.

Ayyildiz, Y., \& Tarhan, L. (2012). The effective concepts on students' understanding of chemical reactions and energy. Hacettepe Üniversitesi J. of Education, 1(42), 72-83.

Bernard, H. R. (2000). Social research methods: Qualitative and quantitative approaches. California: Sage.

Britner, S. L., \& Pajares, F. (2001). Self-efficacy beliefs, motivation, race, and gender in middle school science. J. Women Minor. Sci. Eng, 7(4), 271-285.

Bui, N. H., \& Alfaro, M. A. (2011), Statistics anxiety and science attitudes: age, gender and ethnicity factors, Coll. Student J., 45(3), 573-585.

Calik, M., Ultay, N., Kolomuc, A., \& Aytard, A. (2015). A cross-age study of science student teachers 'chemistry attitudes. Chemistry Edu. Res. and Prac., 16(2), 228-236.

Calik, M., Ozsevgec, T., Ebenezer, J., Artun, H., \& Kucuk, Z. (2014). Effects of 'environmental chemistry' elective course via technology embedded scientific inquiry model on some variables. J. Sci. Educ. Techno., 23(3), 412-430.

Catsambis, S. (1995). Gender, race, ethnicity, and science education in the middle grades. Journal of Research in Science Teaching, 32, 243-257. 
Cheung, D. (2007). Developing an instrument to measure students' attitudes toward chemistry lessons for use in curriculum evaluation. Paper presented at the 38th annual conference of the Australasian Science Education Research Association, Fremantle, Australia.

Cheung, D. (2011). Evaluating student attitudes toward chemistry lessons to enhance teaching in the secondary school. Educ. Quím, 22(2), 117-122.

Cohen, L., Manion, L., \& Morrison, K. (2007). Research methods in education. London: Routledge.

Coll, R. K., Dalgety, J., \& Salter, D. (2002). The development of the chemistry attitudes and experiences questionnaire (CAEQ), Chem. Educ. Res. Pract. Eur., 3(1), 19-32.

Concannon, J. P., \& Barrow, L., H. (2012). A reanalysis of engineering majors' selfeficacy beliefs. J. Sci. Educ. Technol, 21(6), 742-753.

Creswell, J. W. (2009). Research design: Qualitative, quantitative, and mixed methods approaches. Thousand Oaks, CA: Sage.

Dalgety, J., \& Coll, R., K. (2006). Exploring first-year science students' chemistry selfeficacy. Int. J. Sci. Math. Educ, 4(1), 97-116.

Dalgety, J., Coll, K. R., \& Jones, A. (2003). Development of chemistry attitudes and experiences questionnaire (CAEQ). J. of Res. in Science Teaching, 40(7), 649-668.

Dhindsa, H. S., \& Chung, G. (2003). Attitudes and achievement of Bruneian science students. International Journal of Science Education, 25, 907-922.

Doherty, J., \& Dawe, J. (1985). The relationship between development maturity and attitude to school science: An exploratory study. Educational Studies, 11(2), 93-107.

Ferrel, B., \& Barbera, J. (2015). Analysis of students' self-efficacy, interest, and effort beliefs in general chemistry. Chem. Educ. Res. Pract, 16, 318-337.

Fowler, E., J. (2002). Survey research method. Thousand Oaks, CA: Sage

Gardner, P., L. (1975). Measuring attitudes to science. Res. Sci. Educ, 25, 283-289.

Hair, F. J., Black, C. W., Babin, J. B., \& Anderson, E. R. (2010). Multivariate data analysis. New Jersey: Pearson Prentice Hall.

Hair Jr. J. F., Black W. C., Babin B. J., Anderson R. E., \& Tatham R. L. (2006), Multivariate data analysis. New Jersey: Prentice-Hall International.

Harvey, T. J., \& Stables, A. (1986). Gender differences in attitudes to science for third year pupils: An argument for single-sex teaching groups in mixed schools. Research in Science and Technological Education, 4(2), 163-170.

Hill, G., Atwater, M., \& Wiggins, J. (1995). Attitudes toward science of urban seventhgrade life science students overtime, and the relationship to future plans, family, teacher, curriculum, and school. Urban Education, 30(1), 71-92. 
Hofstein, A., Ben-Zvi, R., Samuel, D., \& Tamir, P. (1977). Attitudes of Israeli highschool students toward chemistry and physics: A comparative study. Science Education, 61(2), 259-268.

House, D., J. (1995), Noncognitive predictors of achievement in introductory college chemistry. Res. Higher Educ., 36(4), 473-490.

Hugerat, M., \& Kortam N., (2014), Improving higher order thinking skills among freshmen by teaching science through inquiry. Eurasia Journal of Mathematics, Science and Technology Education, 10(5), 447-454.

Ibrahim, A. R. (2010). Upaya meningkatkan hasil belajar mahasiswa melalui penerapan model pembelajaran think pair and share pada mata kuliah kimia dasar I. Jurnal Forum MIPA, 13(2), 1-5.

Irwanto, Rohaeti, E., \& Prodjosantoso, A. K. (2018a). The investigation of university students' science process skills and chemistry attitudes at the laboratory course. AsiaPacific Forum on Science Learning and Teaching, 19(2): 7.

Irwanto, Rohaeti, E., \& Prodjosantoso, A. K. (2018b). Undergraduate students' science process skills in terms of some variables: A perspective from Indonesia. Journal of Baltic Science Education, 17(5), 751-772.

Irwanto, Saputro, A. D., Rohaeti, E., \& Prodjosantoso, A. K. (2018). Promoting critical thinking and problem-solving skills of preservice elementary teachers through processoriented guided-inquiry learning (POGIL). Int. J. of Instruction, 11(4), 777-794.

Irwanto, Saputro, A. D., Rohaeti, E., \& Prodjosantoso, A. K. (2019). Using inquirybased laboratory instruction to improve critical thinking and scientific process skills among preservice elementary teachers. Eurasian J. of Edu. Res., 80, 151-170.

Ismail, S. A. A., \& Jarrah, A. M. (2019). Exploring pre-service teachers' perceptions of their pedagogical preferences, teaching competence and motivation. International Journal of Instruction, 12(1), 493-510.

Ismiani, S., Syukri., \& Wahyudiati, D. (2017). Pengaruh penerapan metode problembased learning terhadap sikap ilmiah dan hasil belajar biologi siswa kelas vii mts nw 01 kembang kerang. Biota, 10(1), 68-75.

Iyankova, N. V., Creswell, J. W., \& Stick, S. L. (2006). Using mixed methods sequential explanatory design: From theory to practice. Field Methods, 18, 3-20.

Jones, M. G., Howe, A., \& Rua, M. J. (2000). Gender differences in students' experiences, interests, and attitudes toward science and scientists. Sci. Edu, 84, 180-192.

Jones, M. G., \& Wheatley, J. (1990). Gender differences in teacher-student interactions in science classrooms. Journal of Research in Science Teaching, 27, 861-874.

Kassim, A. H. (2014). Implementation of KBSM science curriculum in the state of Perak: Where to? Journal of Applied Research in Education, 18, 67-85. 
Lopez, F. G., \& Lent, R. W. (1992). Sources of mathematics self-efficacy in high school students. Career Dev. Quart, 41(1), 3-12.

Mataka, L. M., \& Kowalske, M. G. (2015). The influence of PBL on students' selfeficacy beliefs in chemistry. Chemistry Education Research and Practice, 16, 929-938.

Menis, J. (1989). Attitudes towards school, chemistry and science among upper secondary chemistry students in the United States. Res. in Sci.\&Tec.Edu., 7(2),183-190.

Mukhtar, M. (2017). Meningkatkan motivasi belajar mahasiswa melalui pembelajaran model problem solving materi stoikiometri. Lantanida Jurnal, 5(2), 93-196.

Myers, R. E., \& Fouts, J. T. (1992). A cluster analysis of high school science classroom environments and attitude toward science. J. Res. Sci. Teach, 29, 929-937.

Nurhayati, S. (2009). Peningkatan hasil belajar pada mata kuliah kimia dasar 1 dengan metode pendekatan modification of reciprocal teaching. Jurnal Inovasi Pendidikan Kimia, 3(2), 21-28.

Nurlita, F. (2008). Penggunaan perangkat pembelajaran berdasarkan masalah untuk meningkatkan pemahaman konsep dan mengembangkan keterampilan berpikir kritis. Jurnal Ilmiah Pendidikan dan Pembelajaran,4(2), 885-901.

Osborne, J., Simon, S., \& Collins, S. (2003). Attitudes towards science: A review of the literature and its implications. Int. Journal of Science Education, 25(9), 1049-1079.

Pajares, F., \& Kranzler, J. (1995). Self-efficacy beliefs and general mental ability in mathematical problem-solving. Contemp. Educ. Psychol, 20(4), 426-443.

Patton, M. Q. (2002). Qualitative research and evaluation methods. Thousand Oaks, CA: Sage.

Popham, W. J. (2005). Classroom assessment: What teachers need to know. Boston: Pearson.

Prabowo, S. A. (2015). The effectiveness of scientific based learning towards science process skill mastery of PGSD students. Indonesian J. of Sci. Edu., 4(1), 15-19.

Renninger, K., \& Hidi, S. (2002). Student interest and achievement: Developmental issues raised by a case study. In A. Wigfield, \& J. S. Eccles (Eds.), A Vol. in the educational psychology series. Development of achievement motivation (pp. 173-195). San Diego, CA, US: Academic Press.

Salta, K., \& Tzougraki, C. (2004). Attitudes toward chemistry among 11th grade students in high schools in Greece. Science Education, 88, 535-547.

Schiefele, U. (1991). Interest, learning, and motivation. Educ. Psyc., 26(3/4), 299-323.

Schmid, S., Youl, D. J., George, A. V., \& Read, J. R. (2012). Efectiveness of a short, intense bridging course for scaffolding students commencing university-level study of chemistry. Int. J. Sci. Educ, 34(8), 1211-1234. 
Smist, J., M. (1993). General chemistry and self-efficacy. Paper presented at the National Meeting of the American Chemical Society, Chicago, IL.

Simpson, R. D., \& Oliver, S, J. (1990). A summary of major influences on attitude toward and achievement in science among adolescent students. Sci. Edu., 74(1),1-18

Stark, R., \& Gray, D. (1999). Gender preferences in learning science. International Journal of Science Education, 21(6), 633-643.

Stangor, C., O. (2004). Research methods for behavioral sciences. Boston: Houghton Mifflin Co.

Taber, K. S. (2011). Building the structural concepts of chemistry: Some considerations from educational research. Chemistry Edu. Res. and Practice in Europe, 2(2), 123-158.

Teddlie, C., \& Tashakkori, A. (2009). Foundations of mixed methods research: Integrating, quantitative, qualitative, approaches in the social and behavioral sciences. Thousand Oaks, CA: Sage.

Uzuntiryaki, E., \& Aydin, Y. C. (2009). Development and validation of chemistry selfefficacy scale for college students. Res. Sci. Educ, 39(4), 539-551.

Villafane, S. M., Garcia, C. A., \& Lewis, J. E. (2014). Exploring diverse students' trends in chemistry self-efficacy throughout a semester of college-level preparatory chemistry. Chemistry Education Research and Practice, 15, 114-127.

Villafane, S. M., \& Lewis, J. E. (2016). Exploring a measure of science attitude for different groups of students enrolled in introductory college chemistry. Chemistry Education Research and Practice, 4(17), 731-742.

Xu, X., Villafane, S. M., \& Lewis, J. E. (2013). College students' attitudes toward chemistry, conceptual knowledge and achievement: structural equation model analysis. Chem. Educ. Res. Pract, 14, 188-200.

Wahyudiati, D. (2016). Analisis efektivitas kegiatan praktikum sebagai upaya peningkatan hasil belajar mahaisswa. Jurnal Tastqif, 14(2), 143-168.

Wahyudiati, D. (2010). Pengembangan perangkat pembelajaran berorientasi model pembelajaran diskusi pada pokok bahasan energi dan perubahannya untuk menumbuhkan sikap ilmiah siswa. Badan Penelitian dan Pengembangan.

Weiner, B. (1985). An attributional theory of achievement motivation and emotion. Psychol. Rev, 92(4), 548-573.

Wiwit, Ginting, M. S., \& Firdaus, M. L. (2013). Penerapan pembelajaran kimia dasar menggunakan media power point 2010 dan phet simulation dengan pendekatan modification of reciprocal teaching berbasis konstruktivisme. J. Exacta, 11(1), 29-32.

Wolf, S. J., \& Fraser, B. J. (2008). Learning environment, attitudes and achievement among middle-school science students using Inquiry-based laboratory activities. Research in Science Education, 38(3), 321-341. 
Youl, D., Read, J., George, A., Masters, A., Schmid, S., \& King M. (2012). Bridging the gap - student understanding and the chemistry bridging course. Paper presented at the Australian Conference on Science and Mathematics Education, formerly UniServe Science Conference.

Zeidan, H.A., \& Jayosi, R. M. (2015). Science process skills and attitudes toward science among Palestinian secondary school students. World J. of Edu., 1(5), 13-24.

Zeldin, A. L., Britner, S. L., \& Pajares, F. (2008). A comparative study of the selfeficacy beliefs of successful men and women in mathematics, science, and technology careers. J. Res. Sci. Teach, 45(9), 1036-1058.

Zusho, A., Pintrich, P. R., \& Coppola, B. (2003). Skill and will: The role of motivation and cognition in the learning of college chemistry. Int. J. Sci. Educ, 25(9), 1081-1094. doi: 10.1080/0950069032000052207. 